\title{
Free radical scavenging and anti-edematogenic activities of Paullinia elegans Cambess., Sapindaceae, leaves extracts
}

\author{
Rodrigo N. Guimarães, ${ }^{1}$ Maria Conceição T. Truitti, ${ }^{2}$ Ciomar A. Bersani-Amado, ${ }^{2}$ Anelise S. $N$. \\ Formagio, ${ }^{1}$ Flávia P. Cardoso, ${ }^{1}$ Willian F. da Costa, ${ }^{1}$ Maria Conceição de Souza, ${ }^{3}$ \\ Maria Helena Sarragiotto ${ }^{*}, 1$
}

\author{
${ }^{1}$ Departamento de Química, Universidade Estadual de Maringá, 87020-900 Maringá-PR, Brazil \\ ${ }^{2}$ Departamento de Farmácia e Farmacologia, Universidade Estadual de Maringá, 87020-900 Maringá-PR, Brazil \\ ${ }^{3}$ Departamento de Biologia, Universidade Estadual de Maringá, 87020-900 Maringá-PR, Brazil.
}

\begin{abstract}
RESUMO: "Atividades sequestradora de radicais livres e anti-edematogênica de extratos das folhas de Paullinia elegans Cambess., Sapindaceae". O extrato etanólico das folhas de Paullinia elegans Cambess., Sapindaceae, e as frações $n$-hexano, clorofórmio, acetato de etila e hidroetanólica, obtidas de seu fracionamento, foram avaliadas quanto às suas atividades anti-edematogênica e sequestradora de radicais livres. $O$ extrato etanólico e a fração hexano produziram inibição significativa $(74,4$ e $76,0 \%$, respectivamente) do edema da orelha induzido pelo óleo de cróton em ratos, em doses de $5 \mathrm{mg}$ /orelha. As frações acetato de etila e hidroetanólica mostraram atividade sequestradora de radicais livres no ensaio de $\mathrm{DPPH}$, com $\mathrm{IC}_{50}$ de 36,7 e de $30,1 \mu \mathrm{g} / \mathrm{mL}$, respectivamente. O fracionamento dos extratos pelo uso de métodos cromatográficos resultou no isolamento do epifriedelanol, ácido 3-O-acetil oleanólico, mistura do stigmasterol 3- $\beta$-O-glucopiranosídeo e sitosterol 3- $\beta$-O-glucopiranosídeo, canferol, canferol 3,7-O- $\alpha$-diramnopiranosídeo, canferol 3-O- $\alpha$-ramnopiranosídeo e 2-O-metil-chiro-inositol. Os compostos foram identificados com base na comparação de seus dados espectroscópicos de RMN com os da literatura.
\end{abstract}

Unitermos: Paullinia elegans, atividade anti-edematogênica, atividade sequestradora de radical livre, constituintes químicos.

\begin{abstract}
Ethanol extract of the leaves of Paullinia elegans Cambess., Sapindaceae, and its hexane, chloroform, ethyl acetate, and hydroethanol fractions were evaluated for their antiedematogenic and free radical scavenging activities. The ethanol extract and the hexane fraction produced statistically significant inhibition (74.4 and $76.0 \%$, respectively) of the ear edema induced by croton oil in mice, observed at doses of $5 \mathrm{mg} /$ ear. The ethyl acetate and hydroethanol fractions showed significant radical scavenging effect in the DPPH assay, with $\mathrm{IC}_{50}$ of 36.7 and $30.1 \mu \mathrm{g} / \mathrm{mL}$, respectively. Fractionation of the extracts through chromatographic methods afforded epifriedelanol, oleanolic acid 3-O-acetyl, a mixture of stigmasterol 3- $\beta$ - $O$-glucopyranoside and sitosterol 3- $\beta$-O-glucopyranoside, kaempferol 3,7-O- $\alpha$-dirhamnopyranoside, kaempeferol-3-O- $\alpha$ rhamnopyranoside and 2-O-methyl-chiro-inositol. The compounds were identified on the basis of their NMR spectral data and comparison with those of literature.
\end{abstract}

Keywords: Paullinia elegans, anti-edematogenic activity, free radical scavenging activity, chemical constituents.

\section{INTRODUCTION}

Paullinia elegans Cambess., Sapindaceae, is found to occur in Brazil, Uruguay, Argentine and Paraguay. In Brazil, this species is known as "cipó-timbó". Chemical studies of the seeds of Paullinia elegans describe the isolation of cis-13-eicosenoic acid, cis-11-octadecenoic acid and 2,4-dihydroxy-3-methylenebutyronitrile (Spitzer, 1995, 1996). Species of the genus are known to contain fatty acids (Spitzer, 1996), and purin alkaloids (Weckerle et al., 2003) as major constituents.

Our preliminary studies on the pharmacological properties of $P$. elegans showed that the ethanol extract of the leaves presented significant inhibition $(79.6 \pm 0.85 \%$, at $10 \mu \mathrm{g} / \mathrm{mL}$ ) of the growth of Trypanosoma cruzi epimastigotes (Truiti et al., 2005), and reduction of the volume of pleural inflammatory exudates in carrageenan induced pleurisy model in mouse, at doses of $500 \mathrm{mg} \cdot \mathrm{kg}^{-1}$ (Truiti et al., 2006).

In the present study we report the results of the 
free radical scavenging and anti-edematogenic activities evaluation of the ethanol extract and its fractions from Paullinia elegans leaves. The chemical composition of the fractions was investigated through chromatographic methods and the isolated compounds were characterized by NMR spectral data and comparison with those reported in literature.

\section{MATERIAL AND METHODS}

\section{General experimental procedures}

NMR spectra were recorded on a Varian Mercury Plus BB spectrometer operating at $300 \mathrm{MHz}$ for ${ }^{1} \mathrm{H}$ and 75.5 for ${ }^{13} \mathrm{C}$, using $\mathrm{CDCl}_{3}, \mathrm{D}_{2} \mathrm{O}$ or $\mathrm{CD}_{3} \mathrm{OD}$ as solvents and TMS as internal standard. Columns chromatographies were performed using Sephadex LH-20 or silica gel 60 Merck (70-230 mesh ASTM). TLC was performed on precoated silica gel $60 \mathrm{G}$ or $60 \mathrm{GF}_{254}$ Merck.

\section{Plant material}

Paullinia elegans Cambess., Sapindaceae, leaves were collected in March 2000 in Porto Rico, Paraná, Brazil. The plant was identified by Dr. Maria Conceição de Souza and a voucher specimen (HNUP 463) has been deposited at the Herbarium of the Biology Department, State University of Maringá, Paraná, Brazil.

\section{Animals}

Male Swiss mice, weighing between 25 and 35 $\mathrm{g}$ were used in the experiments. The animals were kept in boxes for $72 \mathrm{~h}$ at room temperature, on a $12 \mathrm{~h}$ day-night cycle, with food and water ad libitum. The experimental protocols were approved by the Committee for Ethics and Animal Experimentation of the State University of Maringá.

\section{Extract preparation and fractionation}

Air-dried leaves of $P$. elegans (395 g) were exhaustively extracted by maceration with $95 \%$ ethanol at room temperature. Evaporation of the solvent afforded the ethanol extract (35 g). Part of this extract (12.6 g) was dissolved in EtOH- $\mathrm{H}_{2} \mathrm{O}$ 1:1 and partitioned with $n$-hexane, chloroform and ethyl acetate. The solvent was evaporated to give the hexane (1.8 g), chloroform ( $2.8 \mathrm{~g})$, ethyl acetate $(3.0 \mathrm{~g})$ and hydromethanol $(5.0 \mathrm{~g})$ fractions.

\section{Isolation of the constituents}

The $\mathrm{n}$-hexane fraction (1.58 g) was purified on chromatographic column of silica gel, eluting with a mixture of $n$-hexane:ethyl acetate in increasing polarity, to afford epifriedelanol (13.5 $\mathrm{mg})$ and 3-O-acetyl oleanolic acid (99.0 mg). The chloroform fraction (1.8 g) was submitted to a chromatographic column on silica gel, eluting with a mixture of $n$-hexane, ethyl acetate and methanol in increasing polarity, to give a mixture of stigmasterol 3-O- $\beta$-glucopyranoside and sitosterol 3-O$\beta$-glucopyranoside $(154 \mathrm{mg})$. Purification of the ethyl acetate fraction $(700 \mathrm{mg})$ on a silica gel chromatographic column, eluting with a mixture of chloroform and ethanol in increasing polarity, afforded kaempferol (31.2 $\mathrm{mg}$ ), kaempferol 3,7-O- $\alpha$-dirhamnopyranoside $(22.4 \mathrm{mg}$ ) and kaempeferol-3-O- $\alpha$-rhamnopyranoside (10.5 mg). The hydroethanol fraction (504 $\mathrm{mg}$ ) was purified on Sephadex LH-20 to give the same compounds isolated from ethyl acetate fractions together with 2-O-methyl-chiro-inositol (60 mg).The isolated compounds were identified by comparison of their NMR data with those reported in the literature (Agrawal, 1989; Mahato \& Kundu, 1994; Kundu et al., 2000; Abraham et al., 2005).

\section{Anti-inflammatory assay}

Edema was induced in mice by applying $20 \mu \mathrm{L}$ of croton oil solution $(10 \mu \mathrm{g} / \mu \mathrm{L})$ dissolved in $7: 3$ acetone/ water, to the inner surface of both ears, according to Van Arman (1974). A solution $(20 \mu \mathrm{L})$ of the extract and fractions $(0.25 \mathrm{mg} / \mu \mathrm{L})$, or of indomethacin $(0.05 \mathrm{mg} / \mu \mathrm{L})$ was applied to the inner surface of the left ear. The same volume of the solvent of each solution was applied to the right ear as a control. After $6 \mathrm{~h}$, the animals were killed and the ears sectioned in discs of $6.0 \mathrm{~mm}$ of diameter each. The discs were weighed in an analytical balance for the determination of the edema inhibition percentage.

\section{DPPH free radical scavenging assay}

Free radical scavenging activities of the ethanol extract and of the n-hexane, ethyl acetate, and hydroethanol fractions were determined using 1,1diphenyl-1-picrylhydrazyl free radical (DPPH) method. Various concentrations of the samples were added to $3 \mathrm{~mL}$ of daily-prepared methanol DPPH solution $(0.1 \mathrm{mM})$. The mixture was shaken and left to stand at room temperature in the dark. After $30 \mathrm{~min}$, absorbance was measured at 517 $\mathrm{nm}$ against a blank containing all reagents except the test samples. BHT was used as the positive control. Assays were carried out in triplicate.

\section{Statistical analysis}

The results for anti-edematogenic activity are presented as mean \pm standard error of the mean (SEM). The data were submitted to analysis of variance (ANOVA), followed by Tukey's test. $p<0.05$ was considered as the significance level. 


\section{RESULTS AND DISCUSSION}

Application of croton oil to the left ear of the mice induced a very evident inflammatory response by hour 6 . The weight of the ear doubled was compared to the right ear (basal, with no croton oil applied). The effects of the ethanol extract and its fractions on croton oil-induced rat ear edema are shown in Table 1 and Figure 1. The topic application of ethanol extract and hexane fraction produced a significant anti-inflammatory effect $(p<0.001)$ compared to the control groups. The hexane fraction showed a percentage of $76 \%$ of inflammation inhibition, which was comparable to that of indomethacin $(83 \%$ of inhibition). Esters of fatty acids, epifriedelanol and 3-O-acetyl oleanolic acid were isolated from the hexane fraction. The results indicate that the anti-inflammatory activity of the plant can be attributed to these compounds.

The data for free radical scavenging assay are reported in Table 2. The $\mathrm{IC}_{50}$ (Table 2) correspond to the

Table 1. Antiinflammatory activity of Paullinia elegans Cambess., Sapindaceae, crude ethanol extract and its fractions on ear edema induced by croton oil.

\begin{tabular}{lcc}
\hline Samples & Doses $(\mathrm{mg} / \mathrm{ear})$ & Inhibition $(\%)$ \\
\hline Ethanol extract & 5.0 & 74.4 \\
$n$-Hexane fraction & 5.0 & 76.0 \\
Ethyl acetate fraction & 5.0 & 11.4 \\
Chloroform fraction & 5.0 & 26.6 \\
Hydroethanol fraction & 5.0 & 35.4 \\
Indomethacin $^{\mathrm{a}}$ & 1.0 & 83.3 \\
\hline
\end{tabular}

a Indomethacin was used as positive control concentrations for $50 \%$ of inhibition of DPPH and were calculated from the graph of I\% (inhibition percentage) versus extract concentration in $\mu \mathrm{g} / \mathrm{mL}$. The percentage of inhibition of DPPH (I\%) was calculated using the equation: $\mathrm{I} \%:\left(\mathrm{A}_{\text {blank }}-\mathrm{A}_{\text {sample }} / \mathrm{A}_{\text {blank }}\right) \times 100$, where $\mathrm{A}_{\text {blank }}$ is the absorbance of the blank solution and $\mathrm{A}_{\text {sample }}$ is the absorbance of the ethanolic extract or fractions test samples.

The ethyl acetate and hydroethanol fractions exhibited the highest free radical scavenging activity with $\mathrm{IC}_{50}$ of 36.7 and $30.1 \mu \mathrm{g} / \mathrm{mL}$, respectively. The flavonoids kaempferol and its glycoside derivatives, kaempferol 3,7-O- $\alpha$-dirhamnopyranoside and kaempeferol-3-O- $\alpha-$ rhamnopyranoside were identified as the main components of these fractions. The hydroethanol fraction afforded also the sugar 2-O-methyl-chiro-inositol. The antioxidanteffects observed for ethyl acetate and hydroethanol fractions are probably due the presence of kaempferol, since the DPPH free radical activity of this flavonoid has been reported in the literature (Seyoum et al., 2006).

Table 2. DPPH free-radical scavenging activity $\left(\mathrm{IC}_{50}\right)$ of Paullinia elegans Cambess., Sapindaceae, crude ethanol extract and its fractions.

\begin{tabular}{lc}
\hline Samples & $\mathrm{IC}_{50} \mu \mathrm{g} / \mathrm{mL}(95 \%$ confidence limit $)$ \\
\hline Ethanol extract & $76.9(74.2-79.6)$ \\
$n$-Hexane fraction & $457.1(399.4-535.1)$ \\
Ethyl acetate fraction & $36.7(31.2-44.2)$ \\
Hydroethanol fraction & $30.1(28.5-31.5)$ \\
BHT $^{\text {a }}$ & $16.9(14.3-20.1)$ \\
\hline
\end{tabular}

${ }^{a}$ BHT (butylhydroxytoluene) was used as positive control.

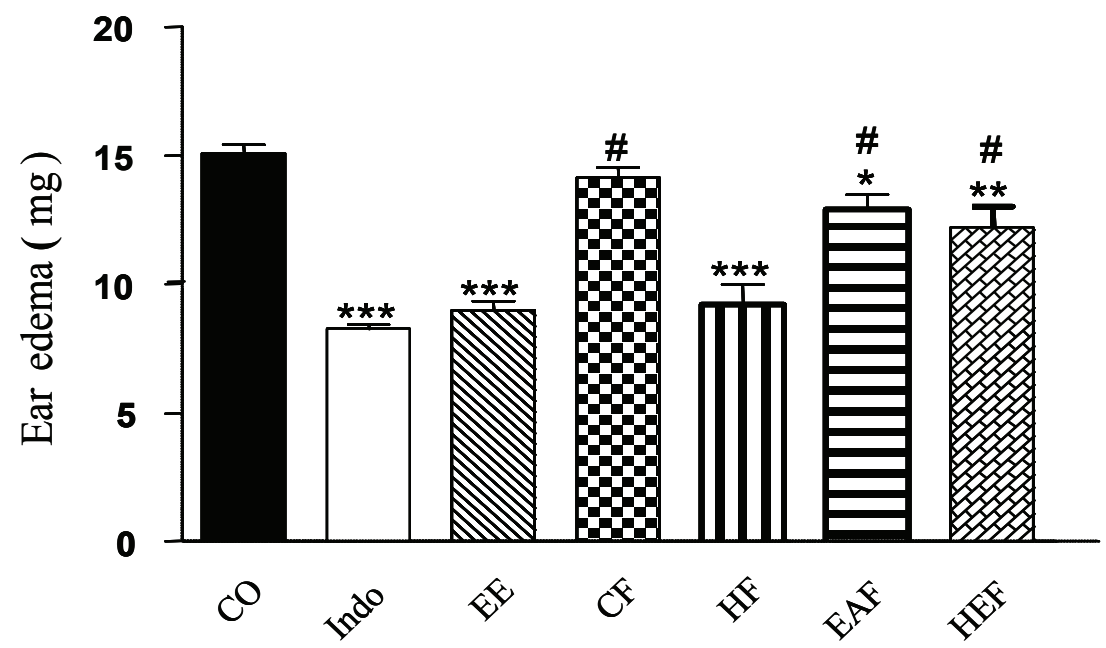

Figure 1. Effect of Paullinia elegans Cambess., Sapindaceae, crude ethanol extract and of the $n$-hexane (HF), chloroform (CF), ethyl acetate (EAF) and hydroethanol (HEF) fractions on ear edema induced by croton oil (CO) (200 $\mu \mathrm{g})$ of male Swiss mice (25-35 g). Samples $(5.0 \mathrm{mg})$ were administered topically. Indomethacin (Indo) $(1.0 \mathrm{mg})$ was used as anti-inflammatory positive control. Each column represents the medium weight of ears \pm E.P.M., $6 \mathrm{~h}$ after croton oil application. $* p<0.05, * * p<0.01$, $* * * p<0.001$, compared to the control groups, $\# p<0,001$, compared to Indomethacin (ANOVA, Tukey test). 


\section{ACKNOWLEDGEMENTS}

We are grateful to CAPES and CNPq for fellowships (A.S.N.F., F.P.C.) and to Fundação Araucária (Paraná State, Brazil) for financial support.

\section{REFERENCES}

Abraham RJ, Byrne JJ, Griffiths L, Koniotou R 2005. H-1 chemical shifts in NMR: Part 22-Prediction of the $\mathrm{H}-1$ chemical shifts of alcohols, diols and inositols in solution, a conformational and solvation investigation. Magn Reson Chem 43: 611-624.

Agrawal PK 1989. Carbon-13 NMR of flavonoids. New York: Elsevier.

Kundu JK, Rouf ASS, Hossain Md.N, Hasan CM, Rashid MA 2000. Antitumor activity of epifriedelanol from Vitis trifolia. Fitoterapia 71: 577-579.

Mahato SB, Kundu AP 1994. C-13 NMR-spectra of pentacyclic triterpenoids-a compilation and some salient features source. Phytochemistry 37: 1517-1575.

Seyoum A, Asres K, El-Fiky FK 2006. Structure-radical scavenging activity relationships of flavonoids. Phytochemistry 67: 2058-2070.

Spitzer V 1995. GLC-MS analysis of the fatty acids of the seed oil, triglycerides, and cyanolipid of Paulliania elegans (Sapindaceae)-a rich source of cis-13-eicosenoic acid (paullinic acid). J High Res Chromatog 18: 413-416.

Spitzer V 1996. Fatty acid composition of some seed oils of the Sapindaceae. Phytochemistry 42: 1357-1360.

Truiti MDT, Bersani-Amado CA, Dias BP, Sarragiotto MH, de Souza MC 2006. Screening of five Brazilian plants for anti-inflammatory and antimicrobial activities. Pharm Biol 44: 516-521.

Truiti MCT, Ferreira ICP, Zamuner MLM, Nakamura CV, Sarragiotto MH, Souza MC 2005. Antiprotozoal and molluscicidal activities of five Brazilian plants. Braz J Med Biol Res 38: 1873-1878.

Van Arman GC 1974. Anti-inflammatory drugs. Clin Pharmacol Ther 16: 900-904.

Weckerle CS, Stutz MA, Baumann TW 2003. Purine alkaloids in Paullinia. Phytochemistry 64: 735-742. 